\title{
FIRST CONTACTS AND THE COMMON BEHAVIOUR OF HUMAN BEINGS
}

\author{
J. van Brakel (K.U. Leuven)
}

abstract

In this paper my aim is to shed light on the common behaviour of human beings by looking at 'first contacts': the situation where people with unshared histories first meet (who don't speak one an others' language, don't have access to interpreters, etc.). The limits of the human life form are given by what is similar in the common behaviour(s) of human beings. But what is similar should not be understood as something that is biologically or psychologically or transcendentally shared by all human beings. What is similar is what human beings would recognise as similar in first or other contacts - a similarity that is, in a way, transcendentally grounded, but the content of this grounding remains tied to the local situation of actual encounters. To be a human person, it is both an empirical and a transcendental precondition that one knows the certainties of particular form(s) of life and that one is capable of recognising and dealing with an indefinite variety of human behaviours. Because I participate in form(s) of life, I can interact with other form(s) of life. By considering first contacts and by interacting with other communities, one can learn to understand better what the common behaviour(s) of human beings is/are. 


\section{the common behaviour of human beings and form(s) of life}

In a well-known passage Wittgenstein wrote: ${ }^{1}$

The common behaviour of mankind [gemeinsame menschliche Handlungsweise] is the system of references [Bezugssystem] by means of which we interpret an unknown language.

Contrary to what it may seem to suggest, this sentence does not imply that Wittgenstein presupposes the existence of any behaviour common to human beings and only human beings. It does not imply that certain patterns of linguistic behaviour are realised in all languages or that some behavioural regularities prevail among all and only human beings. ${ }^{2}$ In this paper my aim is to shed light on the common behaviour of human beings by looking at 'first contacts': the situation where people with unshared histories meet (who don't speak one an others' language, don't have access to interpreters, etc.) - the empirical analogue of the thought experiment of radical interpretation in Davidson's philosophy of language.

The Wittgensteinian notions 'common behaviour of mankind' and 'form of life' are closely connected. There is no reason to identify the two, but both form(s) of life and the common behaviour(s) of human beings stress the human being as a social being, a zoon politikon. ${ }^{3}$ Elsewhere I have suggested that form(s) of life should be understood at the same time in the singular and plural, as local and universal, as empirical and transcendental (van Brakel 2001). There is both one and many human forms of life that crop up and disappear. It would be incorrect to talk of many human forms of life, because all have in common their humanness. It would also be incorrect to talk about one human form of life, because there are innumerable variations without a common core.

Quite a number of interpretations have been offered of (human) form(s) of life and the common behaviour of human beings. First, it has been argued that there is one form of human life: either one natural history or one transcendental form of human life. Second, it has been argued that form of life is roughly synonymous with either culture or language game - so there are many forms of life. The latter quasianthropological interpretations take form(s) of life as variable patterns of activity (i.e. social practices or patterns of expectation and response, which may vary from one tradition to another), rather than as (transcendental) conditions for being human. There are several other views, including the influential work of Cavell (1979), which is difficult to classify. And there are idiosyncracies like the transcendental relativist reading of Bearn (1985). 
What should we $d o$, confronted with these philosophical constructions? The answer is simple: We should give up playing the game in terms of dichotomies or categorical subdivisions. Though Bolton (1982: 275f) noted that 'the concept of life bridges the old dichotomies between idealism and materialism' and Lear (1986: 272) suggested that in 'Wittgenstein's mature thought the transcendental and the anthropological appear to be intended to form a coherent whole', these suggestions have not been developed further. The suggestion that the empirical or natural becomes indistinguishable from the transcendental or a priori in this sort of context, can also be found in the work of Merleau-Ponty (when criticising Husserl). Gadamer too in his critique of Husserl's Lebenswelt can be read in this light. ${ }^{4}$ But although the suggestion of dropping or blurring sharp boundaries is there, it is never brought to the fore. Still, many writers have touched the problematic nature of these boundaries in passing. ${ }^{5}$

I suggest that the common behaviour(s) of human beings should be understood analogously to form(s) of life,i.e. in the singular as well as the plural, as empirical as well as transcendental. ${ }^{6}$ To argue that the common behaviour of human beings (or Wittgenstein's use of 'primitive' or 'natural reactions' or 'natural history') is either a transcendental or a biological universal invariant, is to fall back to the idea of a transcendent observer (be it of the 'foundationalist' a priori or 'naturalist' a posteriori sort). This 'complicated form of life ${ }^{7}$ has many variants, which do not come under one essentialistic definition. What strikes 'us' (or 'them') as part of the common behaviour of human beings is not necessarily exhibited by all human beings. There are 'behaviours of human beings' that are 'common' in the sense that they are (usually, normally, often) recognised as human behaviour by humans who don't display that behaviour themselves (and find it 'incomprehensible', 'despicable', and so on). In addition, all this talk about what is or is not common is phrased in a language embedded in particular form(s) of life, not in the metalanguage that is spoken by the members of some meta-form of life (as philosophers might claim to be). Hence it would be incorrect to think in terms of one common behaviour of human beings (grounded in common innate dispositions or transcendental categories), because there are innumerable variations without a common core. But it would be equally incorrect to talk of a principled difference between many common behaviours (leading to 'relativism', 'incommensurability', and other 'terrible' things), because all have in common that they constitute the behaviour of human beings. There are both one and many common behaviours of human beings that crop up and disappear 


\section{the common behaviour(s) of human beings and first contacts}

The issue of the common behaviour of human beings can be explored with reference to any encounter of two or more human beings, but in particular in connection with so called 'first contacts'. Consider what happened when Cook's ship arrived in March 1778 at Nootka Sound (West Coast of Vancouver Island, Canada), making contact with a group of Nuu-chah-nulth people at the village of Yuquot: ${ }^{8}$

As we were coming [in] we were surrounded by thirty or 40 Canoes full of Indians who expressed much astonishment at seeing the Ship; they stood up in their Canoes, made many strange Motions, sometimes pointing to the shore \& at other times speaking to us in a confused Manner very loud \& shouting, \& presently after they all sung in concert in a wild Manner, ... We made Signs of Friendship to them and invited them along side the Ship where they soon ventured \& behaved in a peaceable manner, offering us their Cloaths \& other things they had in their Canoes, and trading immediately commenced between us; ... Night coming on they all paddled ashore except five or six Canoes which drew in a Cluster together at a small distance from the Ship, and as it were to bid us a good night the people in them sang in concert in no disagreeable Stile; this Mark of their Attention to us we were unwilling to pass over unnoticed \& therefore gave them in return a few tunes on two french Horns after their Song was ended, to these they were very attentive, not a word to be heard among them during the time of playing; this salutation was returned by another Song from the Indians, after which we gave them a Tune on the Drum \& Fife to which they paid the same attention as they had done to the Horns.

Of course this citation is just one version of what went on and this version has already passed through several 'reconstructions' (Clayton 2000: 17-29): Europeans representing the world in relation to themselves and contributing to the constitution of the Pacific as a 'theatre' of empire. But passing over these complications for the moment, note that not only trading commences at once, but also the exchange of songs and music. Lots of complex communicative interaction is taking place without knowing the other's language. First contacts, as illustrated by the encounter in Nootka Sound, show communicative interaction is taking place without sharing or understanding the language of 'the other'. This is not to say that language is irrelevant (or merely an efficient tool). One has some understanding of people's actions and behaviour long before understanding their language, in part because they are using language. But interpretation of their behaviour, ascription of beliefs and other attitudes begin long before one gets a hold on interpreting 
particular utterances. Non-verbal behaviour can be interpreted directly as rational, meaningful, morally wrong, and so on (by the lights of the interpreter of course).

The 'discovery' of Yuquot is told from the Nuu-chah-nulth's point of view rather differently - and also here the version told will be the result of many reconstructions and negotiations. One version tells Cook's vessels were found lost at sea, and brought into the safety of Nootka Sound where they were treated to appropriate ceremonial welcome. The 'official' account of the Mowachaht-Muchalaht, one of the current tribes or bands of the Nuu-chah-nulth, of their first contacts with European ships is as follows: ${ }^{9}$

Captain Juan Perez, sent north in 1774 ... anchored offshore near Yuquot. We sent some canoes to investigate his unusual vessel and tried, by signing, to invite him to visit us at Yuquot. The next day we sent out many canoes to examine the odd people and vessel that had come to visit us. We managed to do very well in barter. By giving up a few furs and used hats, we were able to procure some valuable copper, iron implements, silver utensils and even a few beautiful shells. Unfortunately, before we could gain even more through trade, a small storm blew up and the ship inexplicably left.

In 1778, our chiefs welcomed Captain James Cook and his party ... to our territory at a gathering in the big house [at Yuquot]... We remembered the great trade we had done with Perez's ship [in 1774], and were anxious to secure exclusive trade with these new vessels. To this end, we sent out some of our best canoes and mariners to welcome and assist our visitors. This we were able to do, directing Cook's ship through the fog to an anchorage well within our territory. We were able to bind Cook to us through ceremonial welcome and gift exchange, and to establish and maintain excellent relations with the captain and his crews in the hope that we could attract more visitors. We were very pleased with the trade that ensued, being able to exchange a few trifling furs, combs, spoons and hats for items we greatly valued, in particular iron, axes and cloth. This time, our visitors stayed with us longer and we were able to gain a better understanding of these men in 'floating houses'.

Whether the same people (under Chief Maquinna) met both parties (of Perez and Cook) is contested. But there can be little doubt that the various accounts all refer to the 'same' events that 'really' took place in the 1770s, no matter the (important) variations in the way the story is being (re)told. ${ }^{10}$ There is a great variety in the oral accounts of what happened at these first contacts in and around Nootka Sound (Clayton 2000: 
22-29), but there is reasonable consistency on many factual matters. According to Clayton the native oral histories tend to 'relate a mixture of wonder, astonishment, curiosity, and fear at the sight of strange objects and people', whereas in the journals of Cook and his officiers 'gestures, speeches and songs were registered matter-of-factly'. In contrast, in native accounts 'such actions are invested with supernatural and spiritual meaning'.

In the 1778 event related above, the exchange of music was, most probably, considered in a positive vein on both sides, although the significance for the people from Yuquot was very different. ${ }^{11}$ Here is a case where 'making music' definitely didn't mean the same thing on both sides (Salmond 1991: 21-2). On December 13, 1642 two Dutch ships dropped anchor in Taitapu - Golden Bay (on the coast of the South Island of what is now New Zealand). About an hour later two canoes from a group of four approached them as lights flared up on shore. After a long, silent inspection, ${ }^{12}$

the men in the two prows began to call out to us in a rough, hollow voice, but we could not understand a word of what they said. We however, called out to them in answer, upon which they repeated their cries several times, but came no nearer than a stone-shot; they also blew several times on an instrument of which the sound was like that of a Moorish trumpet.

Salmond comments that the rough calling was probably an incantation or a haka, a chant of war, and the instrument played from the canoes was almost certainly a shell trumpet, sounding to challenge the strangers and signalling that the people in the bay were on the alert. A sailor on the Heemskerck was ordered on deck to play some tunes in answer, and the second mate of the Zeehaen did the same. After these brief and ambiguous exchanges the men in the canoes paddled back to the land in darkness. Though in this case it seems fare to say that there was little understanding of the other (on both sides), this doesn't mean that communicative interaction wasn’t taking place.

Any form of human communication, including non-verbal communication during first contacts, rests on more or less successful attunement of mutual two-way interpretation of utterances and other overt behaviour (e.g. gesture, facial expression, intonation, silence and so on), while simultaneously ascribing beliefs and other attitudes. In interpreting the linguistic and non-linguistic behaviour of the other, it is our secure attunements (those to which we must accede or be declared mad), which we tend to read into the behaviour of others, unless something seems to indicate that it might be a mistake to do so. Conversely 'the 
other' is equally busy interpreting us by means of her secure attunements, attempting to make intelligible our actions, and guess what we are likely to believe, desire, intend, and mean by our words (by her lights of course). Whatever 'meaning' is ascribed to each other's behaviour, will emerge from our adjustments to, and contestation and revision of one another's interpretations. Here, a degree of emotional and moral attunement is as necessary for communication as a 'rough', 'pragmatic' agreement on what is happening in the locally shared world; but there are no 'secure attunements' that have epistemological or metaphysical priority - attunements are fleeting and contestation and revision is always in the air. This makes the actual negotiation of meanings the product of social, political, and ethical forces.

Consider another example from Cook's journeys - coast of New Zealand, April 7, 1773:13

... we should have pass'd without seeing them [i.e. one man and two Women] had not the man holloa'd to us, he stood with his club in his hand upon the point of a rock.... the man seemed rather afraid when we approached the Rock with our Boat, he however stood firm. ...

... The captain then taking some sheets of white paper in his hand, landed on the rock unarmed, and held the paper out to the native. The man now trembled visibly, and having exhibited strong marks of fear in his countenance, took the paper: upon which captain Cook coming up to him, took hold of his hand, and embraced him, touching the man's nose with his own, which is their mode of salutation.... ... presently after we were joined by the two Women, the Gentlemen that were with me and some of the Seamen and we spent about half an hour in chitchat which was little understood on either side in which the youngest of the two Women bore by far the greatest share. We presented them with fish and Wild fowl which we had in our boat, which the young Woman afterwards took up one by one and threw them into the Boat again giving us to understand that such things they wanted not....

Again this is a one-sided account and that side already knows quite a lot about the other side. One reason the account will be biased is because Cook had specific instructions from the British Royal Society of how to deal with the people he was to meet: ${ }^{14}$

To exercise the utmost patience and forbearance with respect to the Natives of the several Lands where the Ship may touch.... They are human creatures, the work of the same omnipotent Author, equally under his care with the most polished European; perhaps being less offensive, more entitled to his favour. ... 
Conquest over such people can give no just title; because they could never be the Aggressors.... There are many ways to convince them of the Superiority of Europeans, without slaying any of those poor people.--for Example.-- ...

Amicable signs may be made which they could not possibly mistake. ... Opening the mouth wide, putting fingers towards it, and then making the motion of chewing, would sufficiently demonstrate a want of food....

No doubt the diaries of Cook and his men reflect those instructions and Cook's concern to fulfil his scientific-civilising mission, in which for the British government, the Royal Society, if not Cook himself, science and empire went hand in hand: all explorer's texts can be viewed as imperial allegories.

Furthermore, Cook could make use of experience of earlier visits in the area in his approach to this new encounter. Can a better interpretation of what was going on at this first contact be gained with the help of accounts of the oral history of the Maori (because that's what the man and two women no doubt were)? Detailed studies exist (see next section), but add little to the specific points I want to make. ${ }^{15}$

Although we only have an 'edited' account from one side, perhaps this is, empirically, the nearest one can get to what's going on in essence in interhuman communication. What is going on is a lot; even though Cook and his men aren't learning very much from the encounter (and basically confirm the picture associated with heroic, humanistic, paternalistic and colonial enterprise history). Still 'everything' is involved: innumerable interpretations and judgements are made of the other person(s) - long before any word is uttered or understood. Cook and his men and, presumably, the man and two women they met, both considered the others as similar to themselves (although not the same). Hence they ascribed to them various properties (of the sort 'we' call emotions, beliefs, desires, intentions, moral judgements, and so on) that made some sense (by the lights of the interpreter).

However, every particular interpretation depends on innumerable other interpretations, each of which can be wrong. Hence there's no fact of the matter to any particular interpretation. For example, the diaries of both Cook and Forster report the man on the rock as being in fear. Perhaps this was true, perhaps not. Perhaps he was angry at their trespassing; that is why he 'holloa'd', shouting: 'Go away!' That's what the man and two women were politely and seriously trying to tell Cook and his gentlemen and seamen in about half an hour in chit-chat and that's what they wanted to say with refusing the fish and wild fowl. (Cook and 
his men could have taken the last gesture as an insult, but they didn't.) But perhaps the man was neither afraid nor angry. Maybe he was trembling from excitement and his 'holloa-ing' was an invitation for somebody to come ashore. Perhaps he was excited or angry, but the trembling had nothing to do with it because he had a trembling illness. What would be the real fact of the matter? Does it matter? Only in rare cases will the 'incorrectness' of one particular interpretation have significant consequences. There is no need to presuppose cross-cultural universals at this point. ${ }^{16}$ To act 'appropriately' is 'measured' relative to the pragmatic success of a very complex process of interaction and does not depend on whether one particular interpretation is right or wrong.

\section{the attitude towards the other}

Broadly speaking, the attitude towards 'the others' is as persons (or 'souls') belonging to a community, an idea expressed with different emphases by a variety of philosophers: ${ }^{17}$

My attitude towards him is an attitude towards a soul. I am not of the opinion that he has a soul.

Presented with the human form we entertain immediately a multitude of however tentative expectations.

If we succeed in interpreting [a bizarre culture] at all, we are committed to treat them as persons. Our interests shall not be limited. They must not stop at our own fate, but must embrace the whole community. This community, again, must not be limited, but must extend to all races of beings. To recognise a featherless biped or dolphin or Martian as a person is to think of oneself and it as belonging to a community.

Why not say that our first gesture of recognition of another person promises a universal solidarity of human beings?

Recognising another as fellow human being is in a certain way inseparable from behaving towards him as a fellow human being.

In a 'successful' first contact (in the eyes of beholders from both sides) it is assumed (on both sides) that for 'the others' there is some way of reciprocating and engaging (to some extent) in shared practices - but, to repeat, how these practices are described (or experienced) may differ very much. The 'one man and two Women', Cook and his Gentlemen and Seamen met, probably did not refer afterwards to the event as 
having 'spent about half an hour in chitchat'. The first contact(s) at Nootka Sound are described (and 'edited') differently in the diaries kept on Cook's ships and in the oral histories of the Nuu-chah-nulth.

Though interaction there always is, it is quite common to overestimate how 'easy' first contact interaction is 'in theory'. Often, as in Neumann (1994: 131), there seems to be the idea that by falling back on the 'ability to communicate gesturally' one might initiate an 'in-between state' and 'a dialogue across difference' ${ }^{18}$ However, the idea of an 'in-between' is a notion that derives its symbolic power from associations with such things as Gadamer's fusing horizons, but neither Gadamer, nor any other philosopher talking about 'in-betweens' or 'intercultural spaces' has ever addressed the situation in first contacts. In so far as we can speak metaphorically of an 'in-between', this is not an in-between of a shared 'minimalistic' basis for communicative interaction, but an area, not only of mutual attunement, but also of contestation. There is no need to aim for the sharing of a 'common language' (Gadamer 1976), 'language of perspicuous contrast' (Taylor 1994) or 'intercultural dialogue' (Tully 1995), neither at the non-linguistic (or 'gestural'), nor at the linguistic level of communication. Whatever 'meaning' is ascribed to each other's utterances and other actions, will emerge from adjustments to, and contestation and revision of one another's interpretations. This applies as much to interpreting the familiar (other/Other) as the foreign (other/Other). Therefore, after having learnt the other's language, the right way to proceed would be not both parties speaking the same language, but each 'Other' speaking his or her own language, because this avoids the usual domination of one language over the other because of prevailing power relations. ${ }^{19}$

By stressing the relevance of looking at first contacts, of course I'm not implying that the interhuman contact will develop well; intentions motivating the interaction may be based on pure self-interest, devious, or worse. But it does mean that violence ('empire-building', 'silence', racism, xenophobia) as well as altruism ('face', moral proximity) figure against the background of having a particular attitude towards 'the other entity'. It even forms the background if there is doubt whether the others are human beings. Examples of Europeans doubting whether the other is human are well documented. But there are many examples from 'the other side' as well. For example, two soldiers of one of the many Spanish expeditions shortly after the extermination of Montezuma's empire by Cortès, lost their way on one of the Caribbean islands and were found by Indians. The latter wondered whether the Spaniards were humans and kept them under water for 
ten minutes. As they were dead when the Indians got them out of the water, they concluded that the Spaniards were humans indeed. ${ }^{20}$

Although first impressions and attitudes are crucial, not too much emphasis should be put on the momentary event of being confronted with a human body or on associating 'soul' with 'human face'. Winch (1987: 165) is no doubt right to explain Wittgenstein's Einstellung zur Seele ('attitude towards a soul') ${ }^{21}$ by saying:

The situation is not that I first recognize my common humanity with others and that this recognition then provides the intellectual justification for my response to certain modalities in my dealings with them. On the contrary it is a recognition which is itself a function of those responses.

And this situation will often apply. Nevertheless, at first encounters often the explicit recognition of the other as a human being does involve 'opinions', is a process that has a time history and crucially involves the actions of the other and often involves extensive deliberation, as the following citations illustrate: ${ }^{22}$

'One of the people hid,' recalls Kirupano, 'and watched them going to excrete. He came back and said,

'Those men from heaven went to excrete over there.' Once they had left many men went to take a look. When they saw that it smelt bad, they said, 'Their skin might be different, but their shit smells bad like ours.'

So how did Wiru finally come to comprehend whites as human? ... I received the somewhat enigmatic reply 'because their arms bend,' i.e. they have elbows, tuku. Tuku is a verb for exchange.

He gave us shell valuables in return for pigs, and we decided he was human.

'At first', says Ndika Wingti, 'we used to wonder why they had come. We thought, "Who are these people?" But when we saw the things they were trading we thought, "We must befriend them now. They must be our people.",

\section{the possibility and relevance of describing first contacts}

As Salmond (1991: 89) points out, the local reactions to events when Cook's Endeavour arrived at the coast of New Zealand 'rested firmly on Maori assumptions about the world' and 'Europeans and their behaviours were grasped (with some puzzlement) in the light of local experience and expectations'. Similarly, 'the Endeavour party mirrored the society from which they came in their accounts of and reactions to the local people'. And Clayton (2000) makes similar comments concerning the encounter at Nootka Sound. But this 
doesn't exclude some access to what happened at these first contacts. For example, Salmond quotes a source reporting Horeta Te Taniwha, who was a child when Cook's Endeavour arrived on their shore in November 1769, recounting (much later in his life): ${ }^{23}$

We had not been long on board of the ship before this lord of these goblins [i.e. Cook] made a speech, and took some charcoal and made marks on the deck of the ship, and pointed to the shore and looked at our warriors. One of our aged men said to our people, 'He is asking for an outline of this land;' and that old man stood up, took the charcoal, and marked the outline of the Ika-a-maui (the North Island of New Zealand).

There is no ground to disbelieve that the event Horeta Te Taniwha remembers may well have actually happened in the brute sense that some human beings were drawing with charcoal on the deck of that particular ship. Of course Horeta Te Taniwha's memory may have been influenced by later (re-) interpretations of the event. The source Salmond is quoting may give a distorted report of what Horeta Te Taniwha said or may be a complete fake. But short of saying nothing, these are not 'reasonable' doubts. ${ }^{24}$ Though any interpretation, whether historiographical, anthropological, post-colonial or whatever, will be underdetermined by 'the data', ${ }^{25}$ it makes little sense to overstate this case and reduce the events to mere texts - if only because of the enormous impact of colonial history that followed these 'first encounters'. Without some sort of non-ethical 'transcendental' violence no encounter whatsoever is really possible and the amount of non-ethical and ethical violence that ensued from these first encounters is an 'unsayable' wrong of enormous proportions that cannot be undone (Derrida 1978: 118ff; Lyotard 1988). But this doesn't mean that no communicative interaction was taking place. It does mean that the 'relationship with the other is not an idyllic and harmonious relationship of communion, or of sympathy through which we put ourselves in the other's place; we recognise the other as resembling us, but exterior to us' (Levinas 1981: 75).

Much can be said in general about how accounts of first contacts will be biased in terms of the dominant form(s) of life in which the event is primarily reported and discussed - and recorded contacts are never symmetrical. ${ }^{26}$ For example, although Dening (1994: 476-80) describes Cook as ‘a very ethnographic man', he is right to point out that the 'natives of the Pacific were possessed in the images made of them' through a 
process by which ways of seeing are made natural and culturally comfortable. Moreover, the 'description of the Other never lost its instrumentality for the interests of self' ${ }^{27}$

On a somewhat different track, Bourdieu (1991) is equally right that Habermas's (1998) notion of an ideal speech situation is based on a fictitious elision of the social conditions of language use. This applies in particular to first contacts at the onset of colonial times. Whatever 'force' speech acts may have (including non-linguistic speech acts), is a power derived from the social institutions in which the utterance of the speech act participates. For example, when Cook is writing in his diary or John Webber is sketching his famous panorama of Nootka sound, they are addressing the British Royal Society and other European institutions and audiences. ${ }^{28}$ And Bourdieu is also right to say 'that "interpersonal" relations are never, except in appearance, individual-to-individual relationships' (Bourdieu 1977: 81). However, like Bakhtin before him, ${ }^{29}$ Boudieu focuses on symbolic power of linguistic exchanges in 'given' speech communities. ${ }^{30}$ As far as first contacts are concerned there are very few studies that address the issue of symbolic power in any other than a rather abstract way. Notwithstanding 'good intentions', there is a tendency in the literature that focuses on issues of power relations or the embedment of recorded events in macro-processes like the spread of colonialism, not to do much more than use first contacts as exotic examples to illustrate whatever is 'the latest' in Eurocentric post-colonialism (Moore-Gilbert 1997).

More recently postcolonial and subaltern studies have emerged (Young 2001). Again, there is very little that applies to first contacts in a concrete way. Moreover, this research hasn't so much shown that no account whatsoever of 'intercultural' events is possible, but has shown in many cases that it can give better accounts of 'how it really was' (which is not the same as claiming to give an account of the one and only way it really was: what is on offer is better knowledge, not a deconstruction of knowledge). ${ }^{31}$

Furthermore, we don't need postcolonial or subaltern studies to get a glimpse of the impact of the onset of the imperial world. Already in 1726 Swift wrote: ${ }^{32}$

For instance, A Crew of Pyrates are driven by a Storm they know not whither; at length a Boy discovers Land from the Top-mast; they go on Shore to rob and plunder: they see an harmless People, are entertained with Kindness, they give the Country a new Name, they take formal Possession of it for the King, they set up a rotten Plank or a Stone for a Memorial, they murder two or three Dozen of the Natives, bring away a Couple more by Force for a Sample, return home, and get their Pardon. Here 
commences a new Domination acquired with a Title by Divine Right. Ships are sent with the first Opportunity; the Natives driven out or destroyed, their Princes tortured to discover their Gold; a free Licence given to all Acts of Inhumanity and Lust; the Earth reeking with the Blood of its Inhabitants: And this execrable Crew of Butchers employed in so pious an Expedition, is a modern Colony sent to convert and civilize an idolatrous and barbarous People.

And already long ago the aftermath of the arrival of Cortès in what is now called Mexico has been described as the largest genocide in human history. On a more local scale, the arrival of the Europeans on the west coast of Vancouver Island, starting with the arrival of Cook in 1787, brought about profound political and economic changes. ${ }^{33}$ Trade, primarily in sea otter firs, brought great wealth to some of the Nuu-chah-nulth chiefs, but the happenstance of Cook's visit exacerbated the geopolitical unbalance in the Nootka region. The continuous power struggles between the various parties at Yuquot caused major political and economic disruption. Chief Maquinna abandoned Yuquot three times in the late 1780s as a result of conflicts with Europeans and had his village site taken from him by the Spanish from 1789-1795. The benefits of the first contacts were even more elusive because the ensuing scarcity of sea otter firs after the initial trade boom, together with imperial geopolitics, meant that the European traders already abandoned Nootka Sound in the late $1790 \mathrm{~s} .{ }^{34}$ As a result of conflicts with traders, settlers, and among themselves ${ }^{35}$ and increasingly due to epidemics for which the Indians had no resistance (small pox, malaria, measles, influenza, typhoid fever), the estimated population of about 25,000 at first contact was reduced to about 3,000 at the end of the nineteenth century. ${ }^{36}$

\section{no need for cross-cultural universals essentialising the common behaviour of human beings}

When communicative interaction is taking place, as in first contacts and all other interhuman interaction, there is always a shared local world, which is as objective as can be, as examples of first contacts show. There's no need to appeal to some cross-cultural universals as a precondition for communication and objectivity, which is presupposed by numerous philosophers, from the analytic as well as the continental tradition. Though no word is understood in first contacts, communication obviously is taking place, sometimes at a quite sophisticated level; sometimes full of misunderstanding (as is so often the case in human interaction - not only in first contacts). So, no practical worries about living in radically incommensurable worlds need creep in. The threat of relativism and incommensurability only arises if one 
sets the standards inhumanly high (craving for 'objectivity' and 'complete understanding'). However, the ease by which communicative interaction starts, even before any word is understood may suggest - along the lines of Chomsky's argument from the poverty of the stimulus - that there must be shared saliences: basic level categories shared by all human beings. How else would it be possible to catch on so easily? But it doesn't follow from the fact that (non-linguistic) communication works that therefore there must be a rock bottom of shared saliences of some basic events and objects that all humans naturally find similar, grounding communicative interaction in shared beliefs about some centrally important classifications of shared stimuli. If this were suggested the questions to be asked should be: ${ }^{37}$

1. How fixed is the core 'we' naturally find similar? Why couldn't part of the periphery take the place of the centre for other 'wes'?

2. How many basic situations are there? Perhaps the number and kind of basic objects and events, the number and type of basic words or sentences, and how borders around basic situations are drawn, depend on the language and situation in which the question is being asked.

3. How much follows from a particular set of saliences in terms of predicting human behaviour? Perhaps as much as from innumerable other possible sets of saliences.

To illustrate these three rhetorical questions consider 'fear', usually considered a biologically grounded emotion that humans share with many animals. If there are intercultural examples of universally shared 'basic cases' of common human behaviour, surely 'displaying fear' must be one of them. Levy (1973:307) tells us about Tahitian ri'ari'a that [i] it only names 'fear as present experience', not 'anticipatory fear' (which is mata' $u$ ), and [ii] ri'ari'a also 'means a mild aversions about certain kinds of food'. Now who is to say that 'present experience' and/or 'mild aversion about certain kinds of foods' is or is not part of the 'core' of 'fear' (and all words from other languages that are usually translated as 'fear')? And who is going to say that 'anticipatory fear' is or is not a case of 'prototypical' fear?

Of course, for interpretation to get started it is necessary that there are similarities in some respects between (very) different common behaviour(s) of human beings. But the fact that different form(s) of life appear similar is no reason to presuppose that there is one core of 'basic level categories', which all human forms of life, necessarily, share. No matter what the circumstances are, the common behaviour(s) of human beings always show similarities (and differences). If there were no (hypothesised) similarities, 
communicative interaction would not come off the ground. It is a necessary requirement for communication (or interpretation or translation) that these similarities appear, but there is no language independent way to say this or guarantee it. How these similarities are understood depends on the form(s) of life one has been exposed to and on the language that is used to express these similarities. Here it helps to keep in mind the title of Cavell's book The Claim of Reason. ${ }^{38}$ What is similar has to be claimed, in first contacts, and, strictly speaking, again and again in every human interaction. The understanding of what is similar is always particularised and not something that is somehow already given (as innate ideas, categorical percepts, basic level words, or whatever).

There is no need to share the same 'natural' ways of grouping things together (apart from the trivial fact that the discriminatory capacities of most humans are more or less similar). Because these capacities are extremely fine grained and to a great extent display modular plasticity, they set no interesting constraints on the formation of concepts. To make this more concrete, consider the differences and similarities between first, Ifaluk song, which has been glossed as 'justified anger', second Ilongot liget (commonly translated as 'anger'), which is considered a highly valued force in Ilongot society, vital to social and personal life, and third, Utku 'anger' - ningaq, qiquq, urulu, or huaq, each of which stresses different aspects of what 'we' call anger. For the Utku 'anger' is never justified; for the Ifaluk 'anger' is always justified. For the Ilongot liget is almost always evaluated positively; for the Utku never. ${ }^{39}$ By ' our' lights, all these people sometimes display anger (though the Utku only rarely). ${ }^{40}$ On that basis one might suggest that the display of 'anger' is a universal, part of the common behaviour of human beings, because there is a core which all 'prototypical' examples of anger share. However, there is no reason why the universal shouldn't be song or liget, which, by the way, are both much more morally and rationally loaded notions than 'anger' ${ }^{41}$

There are all kinds of things human beings share - even if we leave out what humans share with other animals. All humans have a mastery of language; they have beliefs, desires, hopes, emotions, a sense of practicality and morality, a 'deep' awareness of birth and death, and so on. But the latter is an empirical statement made from within particular form(s) of life. It leaves open the possibility of coming across people who consider what 'we' call emotions, events in the world, or people with whom we're at a loss how to gloss our language game of 'believing' in their language. ${ }^{42}$ Hence, for example, Nussbaum's proposals for a common humanity and the existence of associated functions, the realisations of which constitute common 
marks of the human good, cannot claim to be universal as stated. Nussbaum's list of 'capabilities' is full of taken for granted value judgements phrased in a 'local' language. Even those who are sympathetic to Nussbaum note that 'our ability to recognise a common humanity is apt to outstrip any list of criteria that theorists are likely to come up with' (Wolf 1995: 109). ${ }^{43}$ This doesn't mean that the word 'universal' becomes completely meaningless, merely that 'universal' is not a universale. How the notion of universality (or that of rationality or morality) is understood can always be contested again. Put differently (Butler 1996): if there is a ground to use the term 'universal' with justice, than this should leave open the possibility that this local concept of universality is contested by those who did not participate in the formation of that local concept of universality.

\section{concluding remarks}

Perhaps a brief comment is in order concerning Wittgenstein's preference for imagined cases of forms of life or human behaviour, because I used first contacts to elucidate Wittgenstein's notion of the 'common behaviour of mankind'. Wittgenstein uses many examples of 'primitive' and other 'weird' language games. Whether they would give insight in the common behaviour of human beings is a moot point. Many Wittgenstein interpreters have argued that Wittgenstein's imaginary scenarios are 'devices to aid in recovering the naturalness and familiarity of our concepts' (Cerbone 1994: 159), but already the use of 'our' gives away the implicit 'chauvinism'. One of Wittgenstein's examples Cerbone discusses at length is that of imagining colour-shape concepts: 'If people only had colour-shape concepts, they would have a special word for a red square and one for a red circle, and one for a green circle, etc. ${ }^{44}$ No matter how the relevant passages of Wittgenstein might be interpreted, the imagined scenario is an artificial example, fully embedded in our colour grammar: red and green are 'given'; the 'weirdness' of having special words for 'red square' or 'red circle' stares one in the face. This has nothing to do with 'people and their world, as we try to imagine them more completely, [becoming] more and more alien to us' (Cerbone 1994: 177). After considering this reading, Cerbone seems to reject it, but concludes that 'the point is to recover our own familiar concepts as our own and to see the extent to which our (form of) life is inseparable from them' (p. 178 , his emphasis). This is the sort of philosophical navel staring that rejects any reference to empirical (anthropological) examples. A 'real-form-of-life' example would be to consider, say, the cattle-colourpattern terms of African pastoral people. Magnus (1880) already noted that Xhosa people distinguished 
twenty-six cattle 'colours'. Later studies addressed the difficulty of separating colour and cattle idiom in the language of many pastoral peoples ${ }^{45}$ Obvious questions are whether a colour-cum-pattern idiom is applied to cattle, or a cattle idiom to colour-cum-pattern; and in particular whether it makes any sense to enforce a distinction between a colour and pattern vocabulary. Such colour-cum-pattern terms are primarily used for cattle, but can be used for similar colour-cum-patterns of other objects or for 'colours' never seen before. For example, the Mursi (Ethiopia) happily transferred their cattle focused 'colour' terms to highly saturated colours never before seen (Turton 1978: 654). Hence, either one should focus on Wittgenstein's imaginary scenario's which have nothing to do with 'other people' (they only show the boundaries of language of some local we), or, if it is 'other people' we want to include into our philosophical considerations, it is better to consider non-imagined cases. ${ }^{46}$ By filling in examples such as that of cattle-colour-patterns, and by giving more perspicuous presentations of first contacts, the singularity cum plurality of form(s) of life and common behaviour(s) of human beings comes alive.

Notwithstanding the risk of taking accounts of first contacts too much at face value, ${ }^{47}$ I suggest that, in a philosophical context, first contact form(s) of life can serve as a 'life' heuristics for a hermeneutical understanding of communicative interaction and the common behaviour(s) of human beings that is missed by imagined cases (Wittgenstein's preference), ${ }^{48}$ thought experiments (Quine, Davidson), ideal speech situations (Habermas, Benhabib) or shared horizons (Gadamer, Taylor). The 'heuristics' of these philosophers, easily promoted to transcendental certainties, have a much larger risk of being 'ethnocentric' or 'chauvinistic' than 'imperialistic' first contacts.

Notions such as 'form(s) of life' and 'common behaviour(s) of human beings' are the sort of thing that should be understood at the same time in the singular and the plural; at the same time referring to local empirical situations of communicative interaction and to universally necessary conditions for this communicative interaction to be possible. Neither the notion of form(s) of life nor that of the common behaviour(s) of human beings should be essentialised in the way that was or is common for the notion of culture. First there is the transcendental point that in a way the question 'how to make sense or understand a culture other than one's own', is nonsensical, because it uncritically presupposes 'that understanding one's own culture' does make sense (Winch 1997). There is also the empirical observation that "parts of "our" 
culture may be quite alien to one of "us"; indeed some parts of it may be more alien than cultural manifestations which are geographically or historically remote' ${ }^{49}$

The limits of the human life form are given by the similarities that crop up and disappear in the common behaviour(s) of human beings. But what is similar should not be understood as something that is biologically or psychologically or transcendentally shared by all human beings. What is similar is what human beings would recognise as similar in first or other contacts - a similarity that is, in a way, transcendentally grounded, but the content of this grounding remains tied to the local situation of actual encounters ${ }^{50}$ First contacts are a good example of how the conditon humaine is not a scientific fact. To be a human person, it is both an empirical and a transcendental precondition that one knows the certainties of particular form(s) of life and that one is capable of recognising and dealing with an indefinite variety of human behaviours. ${ }^{51}$ Because I participate in form(s) of life, I can interact with other form(s) of life. By considering first contacts and by interacting with other communities, one can learn to understand better what the 'natural' common behaviour(s) of human beings is/are.

Finally, for communicative interaction to work, one doesn't have to share either language or world if they are what many philosophers have supposed the words 'language' and 'world' to mean. What humans share is broadly similar responses to a diversity of forms of life and behaviours of human beings. From the point of view of one language or one form or life, the behaviour of human beings (or forms of life or languages) always show many similarities. If this were not so, communicative interaction would be impossible. It is a necessary requirement for communication (or translation) that these similarities appear to be there. But there is no language independent way to describe them. There are always similarities among the common behaviour(s) of human beings, but what these similarities seem to be is dependent on the forms of life compared and the conceptual resources available to those making the comparisons as well as the forces of symbolic power, imperialism, regimentation, and 'natural' adjustment of the periphery to the centre. 


\section{references}

Bakhtin, M. (1981) The Dialogical Imagination (C. Emerson and M. Holquist, eds.), Austin: University of Texas Press.

Beaglehole, J.C. (ed.) (1967), The Voyage of the Resolution and Discovery 1776-1780, parts 1 and 2, Cambridge: Cambridge University Press.

Beaglehole, J.C. (ed.) (1969), The Voyage of the Resolution and Adventure 1772-1775, Cambridge:

Cambridge University Press.

Bearn, G.C.F. (1985) Relativism as reductio, Mind, 94: 389-408

Bolton, D. (1982) Life-form and idealism, in Idealism Past and Present (G. Vesey, ed.), Cambridge:

Cambridge University Press.

Bourdieu, P. (1977) Outline of a Theory of Practice, Cambridge: Cambridge University Press.

Bourdieu, P. (1991) Language and Symbolic Power, Cambridge: Polity Press.

Bravo, M.T. (1998) The anti-anthropology of highlanders and islanders, Studies in the History of

Philosophy of Science, 29(3): 369-389.

Briggs, J. (1970) Never in Anger, Cambridge MA: Harvard University Press.

Butler, J. (1996) Universality in culture, pp. 45-52 in For Love of Country: Debating the Limits of

Patriotism (J. Cohen, ed.), Boston: Beacon.

Butler, J. (1997) Sovereign performatives in the contemporary scene of utterance, Critical Inquiry, 23: 350377.

Cavell, S. (1979) The Claim of Reason. Wittgenstein, Skepticism, Morality and Tragedy, Oxford: Oxford University Press.

Cerbone, D.R. (1994) Don’t look but think: Imaginary scenarios in Wittgenstein's later philosophy, Inquiry, 37: 159-183.

Clayton, D.W. (2000) Islands of Truth: The Imperial Fashioning of Vancouver Island, Vancouver: UBC Press.

Connolly, B., and R. Anderson (1988) First Contact, Penguin Books.

Conway, G.D. (1989) Wittgenstein on Foundations, Atlantic Highlands NJ: Humanities Press International. 
Crocker, D.A. (1995) Functioning and capability: The foundations of Sen's and Nussbaum's development ethic, part 2, pp. 153-198 in M.C. Nussbaum and J. Glover (eds.), Women, Culture, and Development. A Study of Human Capabilities, Oxford: Clarendon Press.

Cutter, D.C. (1969), The California Coast, Norman OH: University of Oklahoma Press.

Dening, G. (1994) Europe 'discovers' the 'Pacific', pp. 451-483 in Implicit Understanding (S.B. Schmartz, ed.), Cambridge: Cambridge University Press.

Derrida, J. (1978) Writing and Difference, Chicago: University of Chicago Press.

Diaz del Castillo, B. (1800) The True History of the Conquest of Mexico, London: Wright, original Spanish edition 1568; also published as The Discovery and Conquest of Mexico, New York: Farrar, Strauss and Cudahy (1956).

Efrat, B.S. and W.J. Langlois (eds.) (1978) Nu•tka $\bullet$ Captain Cook and The Spanish Explorers on the Coast, Sound Heritage [Victoria B.C.], vol. VII, No. 1.

Eijzenga, H. (1996) Wittgensteins 'Lebensform': een terra incognita?, Tijdschrift voor Filosofie, 58: 277313.

Emmett, K. (1990) Forms of Life, Philosophical Investigations, 13: 213-231.

Evans-Pritchard, E.E. (1940) The Nuer: A Description of the Modes of Livelihood and Political Institutions of a Nilotic People, Oxford: Clarendon Press.

Fischer, H.R. (1987) Sprache und Lebensform, Frankfurt: Athenäum.

Floridi, L. (1998) The importance of being earnest: Scepticism and he limits of fallibilism in Peirce, pp. 47-

60 in C.S. Peirce: Cosmology to Constantinople (J. van Brakel and M. van Heerden, eds.), Leuven University Press.

Fukui, K. (1979) Cattle colour symbolism and inter-tribal homicide among the Bodi, Senri Ethnological Studies, 3: 147-177.

Gadamer, H.-G. (1976) The science of the life-world, in his Philosophical Hermeneutics, Berkeley:

University of California Press.

Garver, N. (1984) Die Lebensform in Wittgensteins Philosophische Untersuchungen, Grazer

Philosophische Studien, 21: 33-54. 
Garver, N. (1991) Naturalism and the transcendental: The case of 'form of life', in Wittgenstein's Place in Contemporary Philosophy (Serafini \& Teghrarian, eds.), Wolfeboro: Longwood.

Geertz, C. (1995) Culture war, The New York Review of Books, November 30, 1995, p. 4-6.

Giddens, A. (1985) Reason without revolution?, pp. 95-121 in Habermas and Modernity (R.J. Bernstein, ed.), Oxford: Polity Press.

Goetsch, P. (1988) Linguistic colonialism and primitivism. The discovery of native languages and oral traditions in eighteenth-century travel books and novels, Anglia Zeitschrift für englische Philologie, 106: $338-359$.

Habermas, J. (1998) On the Pragmatics of Communication, Cambridge: MIT Press.

Hacking, I. (1995) Aloha, aloha, London Review of Books, September 7, 1995, p. 6-8.

Haller, R. (1981) Die gemeinsame menschliche Handlungsweise, in R. Haller (ed.), Sprache und Erkenntnis als soziale Tatsache, Wien: Hölder-Pichler-Tempsky [also in English in his Questions on Wittgenstein, London: Routledge \& Kegan Paul, 1988, ch. 8].

Haller, R. (1984) Lebensform oder Lebensformen? eine Bemerkung zu N. Garvers Interpretation von "Lebensform", Grazer Philosophische Studien, 1: 55-63 [also in English in his Questions on Wittgenstein, London: Routledge \& Kegan Paul, 1988, ch. 9].

Haller, R. (1988) Questions on Wittgenstein, London: Routledge en Kegan Paul.

Halpern, I. and D. Duke (1978) “... A very agreeable harmony.”: Impressions of Nootkan music, Sound Heritage, 7: 63-70.

Heidegger, M. (1971) A dialogue on language, pp 1-56 in his On the Way to Language, San Francisco: Harper Collins.

Hill, J.H. and MacLaury, R.E. (1995) The terror of Montezuma: Aztec history, vantage theory, and the category of 'person', pp. 277-329 in J.R. Taylor and R.E. MacLaury (eds.), Language and the Cognitive Construal of the World, Berlin: Mouton de Gruyter.

Hinman, L.M. (1983) Can a form of life be wrong? Philosophy. 58: 339-351.

Hintikka, M.B. and Hintikka, J. (1986) Investigating Wittgenstein, Oxford: Blackwell.

Hoover,A.L. (ed.) (2000) Nuu-Chah-Nulth Voices, Histories, Objects \& Journeys, Victoria: Royal British Columbia Museum. 
Leahy, M.J. (1991) Explorations into Highland New Guinea, 1930-1935, Alabama: Alabama University Press.

Lear, J. (1984) The disappearing 'we', Aristotelian Society, Supplementary Volume, 58: 219-242.

Lear, J. (1986) Transcendental anthropology, in P. Pettit and J. McDowell (eds.), Subject, Thought and Content, Oxford: Clarendon Press.

Levinas, E. (1981) Otherwise Than Being: Or, Beyond Essence, The Hague: Nijhoff.

Levy, R.I. 1973. Tahitians, Chicago: the University of Chicago Press.

Lockart, J. (1994) Sightings: Initial Nahua reactions to Spanish culture, pp. 218-248 in S.B. Schwartz (ed.), Implicit Understandings, Cambridge: Cambridge University Press.

Lutz, C. (1988) Unnatural Emotions: Everyday Sentiments on a Micronesian Atoll and Their Challenge to Western Theory, Chicago: The University of Chicago Press.

Lyotard, J.F. (1988) The Differend. Phrases in Dispute, Manchester: Manchester University Press.

Mackay, D. (1985) In the Wake of Cook: Exploration, Science \& Empire, 1780-1801, London: Croom

Helm.

Magnus, H. (1880) Untersuchungen über den Farbensinn der Naturvölker, Jena: Fischer.

Malcolm, N. (1982) Wittgenstein and idealism, pp. 249-267 in Idealism Past and Present (G. Vesey, ed.), Cambridge: Cambridge University Press.

Malcolm, N. (1991) The relation of language to instinctive behaviour, pp. 27-47 in J. Hyman (ed.), Investigating Psychology: Sciences of the Mind after Wittgenstein, London and New York: Routledge.

Mamdani, M. (1996) Citizen and Subject: Contemporary Africa and the Legacy of Late Colonialism, Princeton: Princeton University Press.

Merleau-Ponty, M. (1964) Signs, Evanston IL: Northwestern University Press, pp. 98-113.

Moore-Gilbert, B. (1997) Postcolonial Theory, London: Verso.

Mowachaht-Muchalaht First Nations (2000) Yuquot agenda paper, pp. 11-32 in.Nuu-Chah-Nulth Voices,

Histories, Objects \& Journeys (A.L. Hoover, ed.), Victoria: Royal British Columbia Museum.

Muller and Co. (eds.) (1965) Abel Tasman's Journal, Los Angeles: Kovach.

Needham, R. (1972) Belief, Language, and Experience, Oxford: Blackwell. 
Neumann, K. (1994) 'In order to win their friendship': Renegotiating first contact, The Contemporary Pacific, 6 (1) 111-145.

Neumer, K. (2000) 'Die gemeinsame menschliche Handlungsweise’: Das Verstehen des Anderen in Wittgensteins Spätphilosophie, Grazer Philosophical Studies, 58/59: 331-364.

Nussbaum, M.C. (2000a) Women and Human Development. The Capabilities Approach, Cambridge: Cambridge University Press.

Nussbaum, M.C. (2000b) Aristotle, politics, and human capabilities: A response to Antony, Arneson,

Charlesworth, and Mulgan, Ethics, 111: 102-140.

Putnam, H. (1983) Realism and Reason [Philosophical Papers Volume 3], Cambridge: Cambridge

University Press.

Putnam, H. (1988) Representaion and Reality, Cambridge MA: MIT Press.

Raatzsch, R. (1993) Wie viele 'gemeinsame menschliche Handlungsweise'”(PU 206)?, Grazer

Philosophische Studien, 45: 41- 64.

Raatzsch, R. (1994) “Die gemeinsame menschliche Handlungsweise” (PU 206), pp. 529-538 in Analyomen

1 (G. Meggle and U. Wessels, eds.), Berlin/New York: Walter de Gruyter.

Rosaldo, M.Z. (1980) Knowledge and Passion: Ilongot Notions of Self and Social Life, Cambridge:

Cambridge University Press.

Salmond, A. (1991) Two Worlds: First Meetings between Maori and Europeans 1642-1772, New York:

Viking-Penguin.

Salmond, A. (1997) Between Worlds: Early Exchanges Between Maori and Europeans 1773-1815,

Honolulu: University of Hawai'i Press.

Scheman, N. (1996) Forms of life: Mapping the rough ground, pp. 383-410 in The Cambridge Companion

to Wittgenstein (H. Sluga and D.G. Stern, ed.), Cambridge: Cambridge University Press.

Schieffelin, E.L. and R. Crittenden (1990) Like People You See in a Dream, Stanford: Stanford University Press.

Schulte, J. (1990) Kontext, pp. 146-161 in Chor und Gesetz: Wittgenstein in Kontext (J. Schulte, ed.), Frankfurt a/M: Suhrkamp.

Sellars, W. (1963) Science, Perception and Reality, London: Routledge and Kegan Paul. 
Sharp, A. (1997) Justice and the Mãori: The Philosophy and Practice of Mãori Claims in New Zealand since the 1970s, Auckland: Oxford University Press.

Spivak, G.C. (1999) A Critique of Postcolonial Reason: Toward a History of the Vanishing Present, Cambridge MA: Harvard University Press.

Strathern, M. (1992) The decomposition of an event, Cultural Anthropology, 7: 244-254.

Swift, J. (1726) Gulliver's Travels, Oxford: Blackwell.

Taylor, C. et al. (1994) Multiculturalism, Princeton: Princeton University Press.

Todorov, T. (1984) The Conquest of America, New York: Harper \& Row.

Thomas, D. (1996) Transcultural Space and Transcultural Beings, Oxford: Westview.

Tully, J. (1995) Strange Multiplicity: Constitutionalism in an Age of Diversity, Cambridge: Cambridge University Press.

Turton, D. (1980) There's no such beast: cattle and colour naming among the Mursi, Man, 15:320-338. van Brakel, J. (1991) Meaning, prototypes and the future of cognitive science, Minds and Machines, 1: $233-257$.

van Brakel, J. (1994) Emotions as the fabric of forms of life: A cross-cultural perspective, in W.M. Wentworth and J. Ryan (eds.), Social Perspectives on Emotion, Vol. II, Greenwich USA: JAI Press, pp. $179-237$.

van Brakel, J. (2001) Form(s) of life, pp. 336-341 in R. Haller and K. Puhl (eds.) Wittgenstein and the Future of Philosophy. A Reassessment after 50 Years. Papers of the 24th International Wittgenstein Symposium, Kirchberg am Wechsel: Austrian Ludwig Wittgenstein Society.

van Brakel, J. (2002) Varieties of multiculturalism: no need for a shared language, to appear in Whither Multiculturalism? Critical Perspectives from Canada, Belgium and the Netherlands (B.A.C. Saunders and D. Haljan, eds.), Leuven: Leuven University Press.

von Savigny, E. (1991) Common behaviour of many a kind: Philosophical Investigations section 206, in Wittgenstein's Philosophical Investigations (R.L. Arrington and H.-J. Glock, eds.), London: Routledge, pp. 105-119.

Wiggins, D. (1980) Sameness and Substance, Oxford: Blackwell. 
Williams, M. (1999) Wittgenstein, Mind and Meaning. Toward a Social Conception of Mind, London: Routledge.

Winch, P. (1987) Trying to Make Sense, Oxford: Blackwell.

Winch, P. (1997) Can we understand ourselves?, Philosophical Investigation, 20: 193-204.

Wolgast, E. (1994) Primitive reactions, Philosophical Investigations, 17: 587-603.

Young, R.J.C. (2001) Postcolonialism: An Historical Introduction, Oxford: Blackwell. 


\section{NOTES}

${ }^{1}$ Wittgenstein, Philosophical Investigations, par. 206. Cf. 'Our language-game is an extension [Ausbau] of primitive behaviour [Benehmen].' [Wittgenstein, Zettel, par. 545] See for discussion of this theme: Conway (1989), Fischer (1987), Garver (1984, 1991), Haller (1984), Malcolm (1991), Neumer (2000), Raatzsch (1993, 1994), Schulte (1990), von Savigny (1991), Wolgast (1994).

${ }^{2}$ See for exegetical arguments Hintikka and Hintikka (1986: 209): 'There is in Wittgenstein's writings no evidence that he believed in a way of behaviour common to the entirety of mankind.' See also von Savigny (1991), who argues that 'common' should be taken to refer to 'common to all language use', rather than that there would be linguistic or behavioural regularities that prevail among all or only human beings. ${ }^{3}$ Many interpreters make a direct connection between understanding 'form of life' and 'the common behaviour of mankind' or identify them (Malcolm 1982: 257, Garver 1984: 48), but Raatzsch (1993) gives reasons to distinguish them.

${ }^{4}$ Gadamer (1976: 196): "the notion of the "life-world" has a revolutionary power that explodes the framework of Husserl's transcendental thinking'. See also Merleau-Ponty (1964: 106f).

${ }^{5}$ In the literature on form(s) of life alone, doubts have been expressed, not only about the bipartition of the transcendental and the empirical, but also about many other dichotomies. For example: empirical - nonempirical (Bolton 1982: 280, Williams 1999: 80); empirical - logical and analytic - synthetic (Hinman 1983: 345); empirical - formal, formal - material, a priori - a posteriori, and empirical - philosophical (Lear 1986: 271, 279); transcendental - grammatical (Emmett 1990: 224); objectivist - relativist (Scheman 1996: 388); idealist - materialist (Bolton 1982: 276). Cf. Wittgenstein's 'there is no sharp boundary between methodological propositions and propositions within a method.' (Wittgenstein, On Certainty, par. 318). ${ }^{6}$ Haller (1981) has argued that though 'we must look upon "the common behaviour" as a Weltbildtranscending ground', we should not take it as 'a transcendental condition, but simply a fact of experience'. [This is my translation from the German text (Haller 1981: 531); the English translation (Haller 1988: 124) is not reliable.]

${ }^{7}$ Wittgenstien, Philsophical Investigations, p. 174.

${ }^{8}$ Quoted from Samwell's journal, in Beaglehole (1967: 1088). A very similar account is given in King's journal (pp. 1393-5). 
${ }^{9}$ Quoted from Mowachaht-Muchalaht (2000: 19); cf. Clayton (2000: 253n24) and Efrat and Langlois (1978). Some of the trade in artefacts may have been designed to exploit British naiveté and avarice; cf. description of sale's tactics in Beaglehole (1967:1091).

${ }^{10}$ See various contributions in Hoover (2000). Hence Cook's ship was not the first European contact with Vancouver Island. In 1774 the ship of Juan Pérez anchored briefly outside Nootka Sound. There are many similarities between the accounts of these two first contacts. See the diary of Fray Tomas de la Peña in Cutter (1969:178-183). The Mowachaht claim that in both cases they made the contact, but that Pérez never touched land. However that may be, it is plausible that the news of these 'floating houses' quickly spread along the west coast of Vancouver Island.

${ }^{11}$ Cook stayed in Nootka Sound for almost a month; the 'very agreeable harmony' of 'Nootkan music', as well as its frequency, was commented upon in many of the ships' journals. See further Halpen and Duke (1978), who distinguish Paddle Songs, Welcome Songs, Potlatch Songs, Mourning Songs, Wolf Songs, and so on, which all fit to particular occasions.

${ }^{12}$ Quoted by Salmond (1991:2) from Muller (1965: 18-19).

${ }^{13}$ Quoted from Beaglehole (1969: 116). The first and third citation is from the diary of Cook; the second from the diary of Forster.

${ }^{14}$ Quoted from the secret instructions Cook had received from the Royal Society in London (Beaglehole 1969: 514-519).

${ }^{15}$ See Salmond $(1991,1997)$ and the critical discussion of Salmond (1991) in Neumann (1994). The reason for throwing the fish back may be related to the relation of fish and the tapu of Manawaora (Salmond 1991: 387). Detailed studies also exist on the further history of the relations between the Maori and the European invaders of their land and the recent negotiations between the Maori and the New Zealand government (Sharp 1997).

${ }^{16}$ For a critique of the alleged existence of cross-cultural universals for facial expressions of a small number of 'basic' emotions see van Brakel (1994).

${ }^{17}$ Citations are from Wittgenstein (Philosophical Investigations, II iv), Winch (1987: 156), Putnam (1983: 119), Peirce (Collected Papers 2.654), Sellars (1963: 39), Giddens (1985: 117), and Wiggins (1980: 222) respectively. 
${ }^{18}$ But he also says: 'The search for the in-between in the colonial past is indicative of a yearning for an inbetween in the postcolonial present' (Neumann 1994: 131). Thomas (1996) writes at length on 'spaces in between' and about 'first contacts - intercultural spaces invaded and transgressed upon by explorers, both real and fictional,' but he has very little to say about the processes of communicative interaction at first contacts.

${ }^{19}$ See for illustrations and discussion of the issue of 'no need to speak the same language' Tully (1995) and van Brakel (2002). In addition there are issues of 'non-ethical violence' (Lyotard, Derrida) and 'infinite responsibility' (Levinas) that take on extra significance for these 'first encounters' at the onset of colonial and imperial times.

${ }^{20}$ This story may be apocryphal (Diaz del Castillo 1800 [1658]), but its plausibility suffices for my argument.

${ }^{21}$ Compare also: 'The human body is the best picture of the human soul.' (Wittgenstein, Philosophical Investigations, p. 178).

${ }^{22}$ Citations from Connolly and Anderson (1987: 44), Clark (1986) quoted in M. Strathern (1992), A. Strathern (1971: xii), and Connolly and Anderson (1987: 116) respectively. All quotes refer to encounters with the 'highlanders' in Papua New Guinea in the 1930s. On this group of first contacts see also Leahy (1991) and Schieffelin and Crittenden (1990).

${ }^{23}$ Quoted in Salmond (1991: 87-88). Te Taniwha starts his account by saying: 'In the days long past, when I was a very little boy.'

${ }^{24}$ Doubting everything, as Peirce commented concerning Cartesian doubt, is self-deceptive, speculative, useless, deceitful, solipsistic (Floridi 1998).

${ }^{25}$ A case in point is the extensive discussion on the 'cause' of Cook's death (Bravo 1998). Well-known 'authorities' such as Hacking (1995) and Geertz (1995) in reviewing this debate don't come much further than pointing to the old universalism - relativism dichotomy.

${ }^{26}$ As Neumann (1994: 134) points out a subject such as first contact is itself a contested object. Different disciplines compete for it by strategically launching or promoting new discourses. Moreover, the term itself is problematic, as is 'initial encounter', because such terms suggest a meeting on equal terms. 
27 'Haggle if you like over theories of imperialism and the profits and loss of empire, it is nevertheless difficult to point to any individual, no matter how high-flown the declared motivations, whose mediation between native and civilised did not work to his or her own advantage, or who did not try to make it so' (Dening 1994: 476).

${ }^{28}$ Clayton (2000: 31) labels Webber's sketch of Nootka Sound full of ships, canoes and peaceful activity 'Spectacle and surveillance'.

${ }^{29}$ Bahtin is more concerned with the internal workings of more or less given speech communities (in his case that of Russian), then with communication across speech communities. See Bakhtin (1981: 276, 278, $291,294,365)$.

${ }^{30}$ The same would seem to apply to feminist writings on language and power such as Butler (1997). The issue of symbolic power is touched upon in the many studies of the 'first contact' between 'Montezuma' and 'Cortès'. See for example Hill and MacLaury (1995), Lockhart (1994), Todorov (1984). See Clayton (2000) for the 'imperial fashioning of Vancouver Island' and 'Cook's textual fabrication of difference'. A blatant example of symbolic power in philosophy is Heidegger's (1971) essay 'A Dialogue on Language: Between a Japanese and an Inquirer', which, contrary to what the title suggests, is a monologue.

${ }^{31}$ Examples are the detailed, insightful, plausible, and meticulously researched accounts of the microsociology of all actors and events surrounding sati (widow immolation) in India under British rule (Spivak 1999) and Mamdani (1996) on 'customary power' in Africa.

32 The citation from Swift (1726: 326) is from the end of Gulliver's account after his return from the Houyhnhnms. For the 'inverse' satiric strategies of Gulliver's Travels in the context of eighteenth-century linguistic colonialism and primitivism see Goetsch (1988).

${ }^{33}$ See Mackay (1985) and Clayton (2000) for how Cook's voyages set the model for the inter-relationship between exploration, science and empire, which was to govern the response of the 'second' British empire after the loss of the American colonies.

${ }^{34}$ In retrospect the high expectations of the sea otter fir trade with China were mistaken (Mackay 1985).

${ }^{35}$ The trade in muskets by the traders who followed in Cook's footsteps allowed internecine violence to become more destructive, whereas it was fuelled by the rivalry of native groups to acquire access to the European traders. 
${ }^{36}$ The population at Nootka Sound was estimated at about 2,000 in 1778; it was approximately 500 in 1874 ; in 1934 below 100; in 1991 it was 380. (Hoover 2000: 108).

${ }^{37}$ For a defence of such a view, shared by many philosophers, see Lakoff (1987); for a critique van Brakel (1991).

${ }^{38}$ Cf. Putnam's (1988) arguments on why reason cannot be naturalised because it transcends what can be said about it.

${ }^{39}$ The major sources are Lutz (1988) on the Ifaluk, Rosaldo (1980) on the Ilongot and Briggs (1970) on the Inuit.

${ }^{40}$ In parenthesis it may be noted that 'anger' already has a surprising variety of uses among native speakers of English around the world, whereas the etymology of the word 'anger' in English-English shows that its current meaning fades away if one goes back in time.

${ }^{41}$ Utku notions of anger are closely tied to their notion of ihuma, a kind of mix of rationality and morality (Briggs 1970).

${ }^{42}$ See van Brakel (1994: 195-201) and Needham (1972) respectively.

${ }^{43}$ See for a recent statement of her views Nussbaum (2000a, 2000b) and for a detailed critique Crocker (1995).

${ }^{44}$ Wittgenstein, Remarks on Colour III 155; cf. III 130.

${ }^{45}$ See, for example, Evans-Pritchard (1940) on the Nuer; Fukui (1979) on the Bodi; and Turton (1980) on the Mursi.

${ }^{46}$ The chauvinism of imagined cases comes across when Lear (1986) says: 'we imagine various tribal practices not to study them seriously but to cure our (natural) tendency toward conceptual platonism'. This may be true too, but perhaps the main point of Wittgenstein's examples of imagined life forms, is to show that knowledge, norms, etcetera can exist only given a form of life (Eijzenga 1996).

${ }^{47}$ Currently the most detailed account of the events at Nootka Sound is Clayton (2000) who says (p. 29): 'The journals of Cook and his officers ... illuminate the fluidity of observation and diversity of interaction at Nootka Sound. And the Native accounts point to a multi-levelled geography of contact - an articulation of bodies, spaces, and texts - that has been largely lost in discussion of Cook's voyages. These accounts point to the variety and physicality of this encounter, to actions and meanings that could not easily be 
represented or summarised.' This merely endorses the fluidity of any interpretation, but, as far as getting some insight into the necessary and unnecessary preconditions of communicative interaction, do not alter the overall picture.

${ }^{48}$ An exception might be Wittgenstein's Remarks on Frazer's The Golden Bough. However, as Lear (1984: 240) remarks, correctly I think, 'Wittgenstein seems indifferent to the study of any particular community'. ${ }^{49}$ Winch (1997: 198); see for discussion of this point also Scheman (1996).

${ }^{50} \mathrm{Cf}$. 'we can see in different ways of life something like our own, so that we can find at least some sense in them' (Bolton 1982: 282).

${ }^{51}$ Cf. von Savigny (1991: 108): 'the indefiniteness of the number of languages is precisely due to the indefinite number of possible variations of forms of life.' 